\title{
Kpamkue сообщения
}

УдК 547.963 .3

\author{
АНАЛИЗ СОДЕРЖАНИЯ \\ ГЛОБИН-КОДИРУЮЩИХ ПОСЛЕДОВАТЕЛЬНОСТЕЙ В ЯДЕРНЫХ \\ И ЦИТОПЛАЗМАТИЧЕСКИХ ФРАКЦИЯХ РНК \\ ПРИ ТЕРМИНАЛЬНОИ ДИФФЕРЕНЦИРОВКЕ \\ ЭРИТРОИДНЫХ КЛЕТОК ГОЛУБЯ
}

\section{В. 3. Тарантул}

Проблеме регуляции экспрессии глобиновых генов посвящено много различных исследований $[1-5]$. Основной вывод, вытекающий из проведенных работ, заключается в том, что главным уровнем регуляции этих генов является транскрипционный. Однако до сих пор остается епе мпого неясных вопросов. В частности, практически не исследованы закономерности изменения регуляции экспрессии глобиновых генов в клетках эритроидного ряда по мере их созревания. Для их выяснения нами предпринята попытка проанализировать содержание глобин-кодирующих последовательностей в различных фракциях PHK при терминальной дифференцировке эритроидных клеток голубя. Проведенные расчеты основаны на результатах нашнх ранних исследований и некоторых новых данных [6-8].

Совокупность свсдений, имеющихся в литературе [3, 9-11], позволяет ститать, что основпье этапы иосттранскрипционных изменений гиобиновы пре-мРНК протекают по схеме: $\geqslant 45 \mathrm{~S}$ яРНK $(\sim 12000$ н. $) \rightarrow 28 \mathrm{~S}$ яPHK $(\sim 5000$ н. $) \rightarrow 15 \mathrm{~S}$ яРНК $(1800$ н.) $\rightarrow 9 \mathrm{~S}$ мРHK $(600$ гі.).

Для определения эффективности транскрипции $\alpha$-и $\beta$-глобиновых генов при терминальной дифференцировке анализировали фракции новообразованных гигантских $(\geqslant 45 \mathrm{~S})$ ядерных PHK (яPHK), выделенных из клеток костного мозга (эритробластов) и лериферической крови (ретикулоцитов) анемизированиых голубей, как описано ранее [12]. Препараты меченой РНҚ, очищенные предварительно в градиепте концентра. цин сахарозы, содержащем $85 \%$-ный формамид, фракционировали на колонке с глобиновыми кДНК, пришитыми к целлюлозе [13]. Гибридизацию проводили в течение 12 ч в присутствии $10 \%$-ного декстрансульфата при постоянном перемешивании суспензии кДНК-целлюлозы в растворе РНК, В результате этих эксперииентов определили, что глобин-кодирующис молекулы составляют $0,032 \pm 0,003$ и $0,212 \pm 0,015 \%$ в эритробластах и ретикулоцитах соответственно. Эти значения получены после вычитания фона (в аналогичных условиях с колонкой связывалось $0,008 \%$ [ $\left.{ }^{3} \mathrm{H}\right] \mathrm{pPHK}$ ). На основании известной сложности яРНК $\left(3,6 \cdot 10^{8}\right.$ н. в эритробластах и $1,6 \cdot 10^{8}$ н. в ретикулоцитах [8]), а также учитывая представленность различных молекул РНК в ядрах этих клеток, определенную на основании кинетики гибридизации уникальных последовательностей ДНК с избытками яРНК (в среднем 0,12 и 0,04 копии на ядро в эритробластах и ретикулоцитах соответственно), можно рассчитать, что наиболее сложный класс молекул составляет по массе $2,0 \%$ в эритробластах и $1,1 \%$ в ретикулоцитах. Принимая, что $\geqslant 45 \mathrm{~S}$ гяРНК составляет $1 / 2$ часть сложной фракции и основываясь на данных по содержанию РНК в ядрах и цитоплазме эритробластов $(1,35$ и 1,55 пг соответственно) и ретикулоцитов (0,33 и 0,95 пг соответственно) [5], можно рассчитать по доле $\geqslant 45 \mathrm{~S}$ яРНК, связывающейся с кДНК-целлюлозой, число глобинкодирующих молекул. Необходимо только учесть, что при фракционировании размер молекул РНК уменьшался примерно в 2,5 раза. Число глобин-кодирующих молекул, согласно этим расчетам, в обоих случаях равно примерно двум на ядро. Эта оценка близка к имеюшимся в литературе для эритроидных клеток птиц $[1,14]$. При этом, 
однако, следует иметь в виду, что сделанные допущения не позволяют считать полученное значение числа копий абсолютным. Оно верно только в том, что два типа эрнтроидных клеток содержат одинаковое число глобин-кодирующих молекул $\geqslant 45 \mathrm{~S}$ яРНК. Поскольку представленность таких молекул в $30-80$ раз выше, чем в среднем представлены в ядрах неглобиновые молекулы яРНК (см. выше), на основании полученных данных можно заключить, что эффективность транскрипции глобиновых генов сходна в обоих исслсдованных типах эритроидных клеток и существенно выше, чем таковая других (неглобиновых) генов.

Ранее нами было продемонстрировано наличие глобин-кодирующих последователынстей во фракции $28 \mathrm{~S}$ яРНК эритробластов и ретикулоцитов голубя [6]. Согласно кинетическим кривым гибридизации 28S нерибосомной яPHK этих клеток глобин-кодирующие последовательности составляют 0,008 и $0,07 \%$ соответственно. Из этих значений, зная абсолютные количества PHK в ядре (фракция 28S РНК составляет $2 / 3$ яРНК) и принимая размер молекул 28S PHK равным 5000 н., легко рассчитать содержание молекул яРНК с коэффициентом седиментации 28S, несуцих глобиновые последоватсльности. Исходя из этого, число таких молекул в эритробластах равно 40 , а в ретикулоцитах - 200. Следовательно, в результате процессинга происходит накопление глобин-содержащих молекул $28 \mathrm{~S}$ я РНК в обоих типах эритроидных клеток, но в ретикулоцитах зто накопление более значительное. За счет разной зффективности посттранскрипцинных процессов во фракции $28 \mathrm{~S}$ яРНК ретикулоцитов содержится в пять раз больше молекул, кодируюших глобин, чем в эритробластах.

В этой связи представлялось интересным оценить разницу в содержании глобиновых мРНК в цитоплазме различных типов эритрондных клеток. Основываясь на ранее полученных данных $[6,7]$, согласно которым глобиновые поли $(A)+$ мРНК составляют 0,08 и $0,6 \%$ цитоплазматической РНК эрнтробластов и ретикулоцитов соответственно, и зная абсолютное содержание РНҚ в цитоплазме этих клеток (см. выне), можно рассчитать число молекул глобиновых мРНК на клетку. Оно равно в ретикулопитах 18000, а в эритробластах 3800. Таким образом, в цитоплазме обоих типов эритроидных клеток, находящихся на разных стадиях дифференцировки, как и в $28 \mathrm{~S}$ я РНК, имеет место 5-кратное различие в содержании молекул глобин-кодирующих РНК. Следовательно, наблюдаемое различие в содержании цитоплазматических поли $(\mathrm{A})+$ глобиновых мРНК в ретикулоцитах по сравнению с эритробластами достигается уже на первых этапах процессинга первичного продукта транскрипиии глобнновых генов.

IІолученные данные указывают на то, что накопление такой специализированной МРНК, как глобиновая, происходит за счет усилсния транскрипции уже на ранних стадиях дифференцировки и повышения эффективности процессинга пре-мРНК по мере созревания эритроидных клеток. Эти результаты находятся в соответствии с расчетами [1], согласно которым большие количества специализированных мРНК достигаются за счет регуляции как на транскрипционном, так и на посттранскрипционном уровнях.

Автор выражает признательность проф. К. Г. Газаряну за обсуждение работы и полезные указания.

\section{ANALYSIS OF THE CONTENT OF GLOBIN-CODING SEQUENCES IN NUCLEAR AND CYTOPLASMIC FRACTIONS AND RNA DURING THE PIGEON ERYTHROID CELLS THERMINAL DIFFERENTIATION}

\section{Z. Tarantul}

Institute of Molecular Genetics, Academy of Sciences of the USSR, Moscow

Sum m a ry

The number of RNA molecules coding the sequences of $\alpha$ - and $\beta$-globin in different nuclear and cytoplasmic RNA fractions is culculated for erythroblasts and reticulocytes. The main changes in globin genes regulation of expression during therminal differentiation of erythroid cells of pigeon are shown to occur at the level of pre-mRNA processing. 
1. Tobin A.J. Evaluating the contribution of posttranscriptional processing to differential gene expression // Develop. Biol.- 1979.-68, N 1.-P. 47-58.

2. Groudine M., Weintraub $H$. Activation of globin genes during chicken development // Cell.-1981.-24, N 2.- P. 393-401.

3. On pre-messenger RNA and transcriptions. $\Lambda$ review / K. Scherrer, M.-T. ImaizumiScherrer, C.-A. Reynaud, A. Therwath //Mol. Biol. Repts. - 1979.-5, N 1.- P. 5-28.

4. Harrison P. R. Molecular analysis of erythropoiesis. A current appraisal // Exp. Cell Res. $-1984 .-155$, N 2.- P. $321-344$.

5. Gazaryan $K, G$. Genome activity and gene expression in avian erythroid cells //Int. Rev. Cytol-1982.-74-P. 95-126.

6. Последовательности, кодирующие глобин, в $28 \mathrm{~S}$ пре-мРНK и в цитоплазматической PНК эритроидных клеток голубя / К. Г. Газарян, В. И. Дубовая, Н. С. Незнанов и др. // Молекуляр. биология.- 1980.-14, № 4.-С. 766-772.

7. Tarantul V. Z., Dubovaya V. I., Neznanov N. S. Globin-coding sequences in nuclear and cytoplasmic RNA of pigeon erythroid cells// IX Int. symp. of structure and function of erythroid cell.-Berlin, 1980.- P. 82.

8. Moderatelly repetitive sequences of the pigeon genome transcribed in erythroid cells: transcription assessment and cloning / V. Z. Tarantul, V. A. Goltsov, V. I. Dubovaya et al. // Biomed. et biochim. acta - 1984.-43, N 1.-P. 48-50.

9. Тарантул B. 3., Газарян K. Г. Гетерогенная ядерная РНК: структура и функция // Успехи биол. химин.- 1982.-22.-C. $26-62$.

10. Кавсан B. M. Неоднозначность границ транскрипции эукариотических генов // Биополимеры и клетка.- 1987.-3, № 3.- С. 115-127.

11. Broders $F$., Scherrer $K$. Transcription of the alpha globin gene domain in normal and AEV-transformed chicken erythroblasts: mapping of gigant globin-specific RNA including embryonic and adult genes // Mol. and Gen. Genet.- 1987.-209, N 2.P. $210-220$

12. Метаболически стабильные классы ядерной РНК информационного типа / К. Г. Газарян, Е. Д. Кузнецова, И. В. Фетисова, В. 3. Тарантул// Молекуляр. бнология.1979.-13, № 4.- C. 761-768.

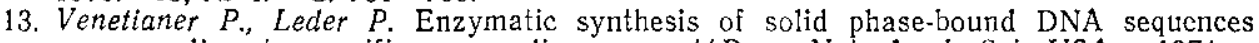
corresponding to specific mammalian genes // Proc. Nat. Acad. Sci. USA.-1974.71, N 10.- P. $3892-3895$.

14. Reynaud C.A., Imaizumi-Scherrer M.-T., Scherrer $K$. The size of the transcriptional units of the avian globin genes defined at the pre-messenger RNA level//J. Mol. Biol.- 1980.-140, N 4.- P. 481-505.

Ин-т молекуляр. генетики АН СССР, Москва

Получено 12.01 .88

$3 \mathrm{l}$

ФАКТОР ИНИЦИАЦИИ 3 (IF-3)

Escherichia coli ЯВ.ЛЯЕТСЯ СУБСТРАТОМ ДЛЯ ЛЕЙЦИЛ(ФЕНИЛАЛАНИЛ) -тРНК-ЛРОТЕИН ТРАНСФЕРАЗЫ*

\section{Н. В. Белицина}

Фактор инициации 3 (IF-3) E. coli играет определяющую роль в узнавании мPHK в процессе инициации трансляции [1]. Известны две формы IF-3 (длинная и укороченная) $-\alpha$ и $\beta$ [2], или $]$ и S [3]. В препаратах $\mathrm{IF}-3$ в виде миноров встречаются также 1-форма без концевого метионина, содержащая лизин с $\mathrm{N}$-конца, и s-форма, которая с $\mathrm{N}$-конца имеет аргинин [4].

Лейцил (фенилаланил)-тРНҚ-протеин трансфераза $E$. coli (EC 2.3.2.6) переносит аминокислотные остатки из аминоацил-тРНК только на те субстраты, которые на $\mathrm{N}$-конце имеют положительно заряжснную аминокислоту (аргиниі, лизин, гистидин) [5]. Так, в частности, субстратом являются $\alpha_{s t}$-казеин и $\beta$-казеин. При этом c N-конца полипептид удлиняется на одну аминокислоту: лейцин, фенилаланин или метнонин. Фермент использует для этого Лей-тРНКЛен, Фен-тРНКөев и элонгаторную МеттPHK ${ }^{\text {мет }}$ [6]. До сих пор в $E$. coli не был идентифицирован белок, который являлся бы субстратом для Лей (Фен) -тРНК-протеин трансферазы.

В настояцей работе приведены данные о перенесении лейцина, фенилаланина и метионина из соответствующих аминоацил-тPHK в IF-3. Из двух его полипептидных

* Представлена членом редколлегии А. В. Ельской. 